日心第71回大会 (2007)

第2日 9 月19日（水） $13: 30 \sim 15: 30 \quad 6218$

\title{
WS064 高齢者の性差
}

〜 健康 - 長寿 - 知恵の性差とその影響〜

$\begin{array}{lllll}\text { 企 画 者 } & \text { 明治学院大学 } & \text { 佐藤 } & \text { 眞一 } \\ \text { 企 画 者 } & \text { 筑波大学 } & \text { 大川 } & \text { 一郎 } \\ \text { 司 会 者 } & \text { 東海大学 } & \text { 谷口 } & \text { 幸一 } \\ \text { 話題提供者 } & \text { 文化女子大学 } & \text { 安永 } & \text { 明智 } \# \\ \text { 話題提供者 } & \text { 東京都老人総合研究所 } & \text { 稲垣 } & \text { 宏樹 } \\ \text { 話題提供者 } & \text { 慶應義塾大学 } & \text { 高山 } & \text { 緑 } \\ \text { 指定討論者 } & \text { 桜美林大学 } & \text { 長田 } & \text { 久雄 }\end{array}$

\section{概 要}

高齢者の性差は極めて多様である。そもそも平均寿命が男女で異なることは良く知られている。2005 年の 日本人の平均寿命は、男性 78.53 歳、女性 85.49 歳で、男女差は 6.96 歳であった。1956 年の男性 63.60 歳、 女性 67.75 歳、男女差 4.15 歳に比べて、約 50 年間で 2.81 歳拡大した。その他、高齢期うつ病の有病率、認 知症の有病率、1 人暮らし高齢者の比率、収入、自殺率・・・。あらることに性差が認められる。うつ病 は女性の方が 2 倍以上も多い。認知症の有病率は、脳血管性認知症の比率が高い前期高齢層では男性が多く、 アルツハイマー型認知症の比率が高い後期高齢層では女性が多い。いずれにしても、高齢者の性差は若い世 代以上に顕著である。したがって、研究はもとより高齢者を論じるあらゆる場面において、男女の違いを意 識することは不可欠である。また、性差そのものの発現機序からその対応まで、研究の必要性は広範囲にわ たっている。本ワークショップでは、健康、長寿、および知恵における性差の実態とその意味を検討する。 